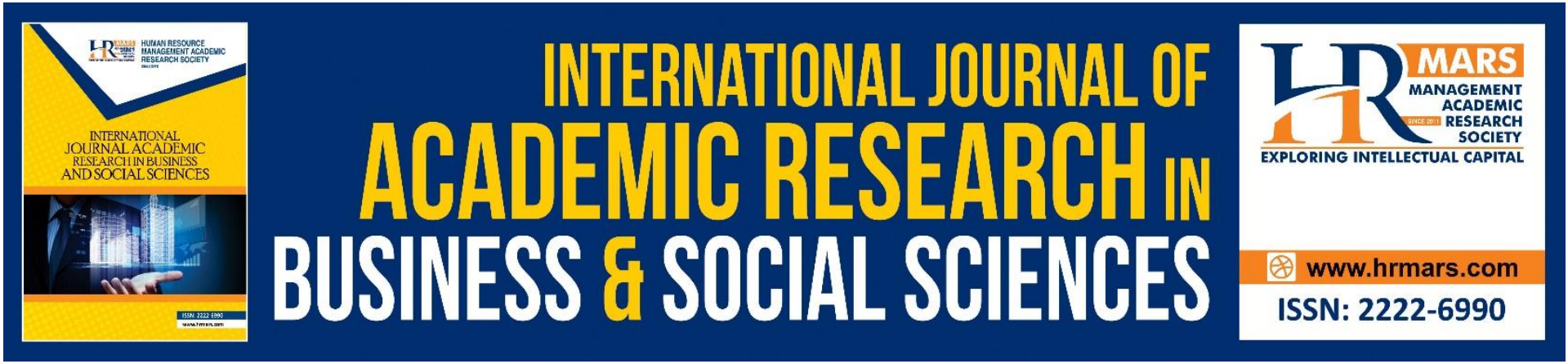

\title{
Corporate Sustainability Reporting and Firm's Financial Performance in Emerging Markets
}

\author{
Wan Adibah Wan Ismail, Sazilah Mohd Saad, Nor Asma Lode, Nanik \\ Kustiningsih
}

To Link this Article: http://dx.doi.org/10.6007/IJARBSS/v12-i1/11364

DOI:10.6007/IJARBSS/v12-i1/11364

Received: 07 November 2021, Revised: 11 December 2021, Accepted: 25 December 2021

Published Online: 13 January 2022

In-Text Citation: (Ismail et al., 2022)

To Cite this Article: Ismail, W. A. W., Saad, S. M., Lode, N. A., \& Kustiningsih, N. (2022). Corporate Sustainability Reporting and Firm's Financial Performance in Emerging Markets. International Journal of Academic Research in Business and Social Sciences, 12(1), 396-407.

Copyright: @ 2022 The Author(s)

Published by Human Resource Management Academic Research Society (www.hrmars.com)

This article is published under the Creative Commons Attribution (CC BY 4.0) license. Anyone may reproduce, distribute, translate and create derivative works of this article (for both commercial and non0-commercial purposes), subject to full attribution to the original publication and authors. The full terms of this license may be seen at: http://creativecommons.org/licences/by/4.0/legalcode

Vol. 12, No. 1, 2022, Pg. $396-407$

Full Terms \& Conditions of access and use can be found at http://hrmars.com/index.php/pages/detail/publication-ethics 


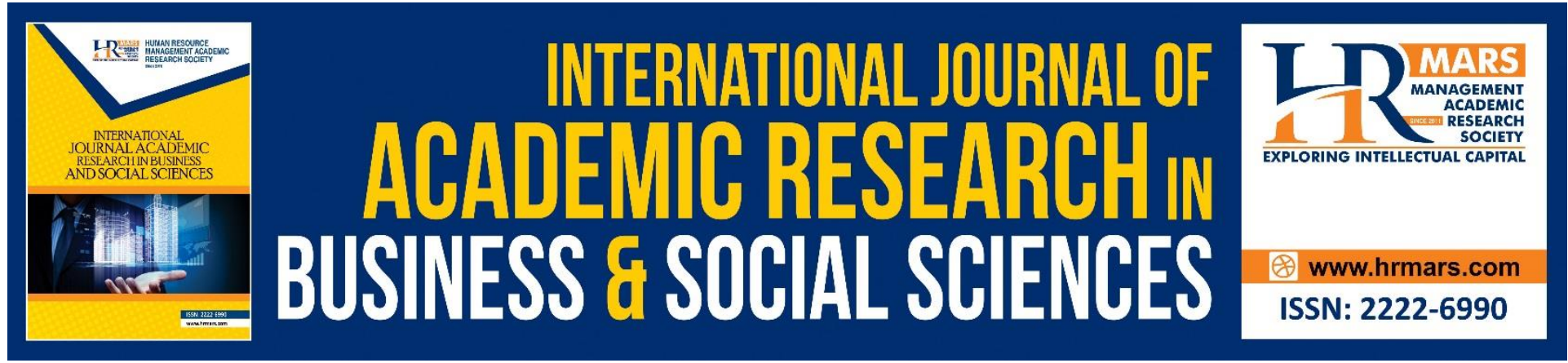

\title{
Corporate Sustainability Reporting and Firm's Financial Performance in Emerging Markets
}

\author{
Wan Adibah Wan Ismail \\ Associate Professor Faculty of Accountancy Universiti Teknologi Mara Merbok, Kedah, \\ Malaysia \\ Email: wadibah@uitm.edu.my
}

\begin{abstract}
Sazilah Mohd Saad
Senior Lecturer Faculty of Accountancy Universiti Teknologi Mara Merbok, Kedah, Malaysia

Email: sazilah@uitm.edu.my
\end{abstract}

\author{
Nor Asma Lode \\ Associate Professor Tunku Puteri Intan Safinaz School of Accountancy Universiti Utara \\ Malaysia Sintok, Malaysia \\ Email: asma@uum.edu.my \\ Nanik Kustiningsih \\ Doctoral Student Faculty of Economics and Business Universitas Airlangga Surabaya, \\ Indonesia \\ Email: nanik.kustiningsih-2017@feb.unair.ac.id
}

\begin{abstract}
This paper investigates whether corporate sustainability reporting is associated with high firm performance in emerging markets. Using a sample of 24,029 firm-year observations from 14 emerging markets, including China, Egypt, Greece, Hungary, India, Malaysia, Pakistan, the Philippines, Poland, Russia, South Africa, Thailand, Turkey and the United Arab Emirates, we find firms with corporate sustainability reporting is associated with high firm performance. The results are robust even after including the firm-level controls of firm size, leverage, litigation risk, market-to-book ratio, firm age, industry-level control of market competition, and country-level control of the gross domestic product. The findings from this cross-country study provides significant implications for the regulators in promoting sustainability reporting and in assisting investors in making better decisions.
\end{abstract}

Keywords: Sustainability Reporting, Integrated Reporting, Stakeholders' Interests, Firms Performance, Emerging Market 


\section{Introduction}

Issues on corporate sustainability has become under spotlights in recent years, especially with the emergence of Covid-19 pandemic throughout the world. The pandemic has imposed great challenge to corporate business owners and managers due to restriction of human movement and business operations. Stakeholders and managers are not only concern on optimizing firms profitability and performance, but also on the disclosure of information of whether the business is sustainable and creating values to larger stakeholders. Thus, the disclosure relating to company's sustainability in terms of its economic sustainability and competitive advantage, environmental sustainability and social communities' sustainability are vital for companies to assess its potential financial and operational risks, manage their natural resources and capture timely business opportunities, which could translate into better financial performance.

Work considering the importance of sustainability reporting to the growth and performance of firms has a rich background. Sustainable reporting derives originally from corporate social responsibility reporting (CSR), now includes wider elements to cater the needs of information on firm's value for various stakeholders. Global Reporting Initiative (GRI) was formed to help businesses, governments and other organizations understand and communicate their impacts on issues including environmental concerns, governance, human rights and corruption. GRI provides framework and standards for the preparation of sustainable reporting that enable third parties to assess environmental impact from the activities of the company and its supply chain. In essence, the reports complement corporate financial statements as it provides more communication about an organisation's strategy, nonfinancial performance, governance, prospects, and external environment. (Al Hawaj \& Buallay, 2021; Ismail et al., 2005). Melloni et al (2017), suggested that the firm's financial and sustainability should communicate "concisely" about how a firm's strategy, governance, performance and prospects, in the context of its external environment, lead to the creation of sustainable value. Hence it will portray a "complete and balanced" report, i.e., broadly including all material matters, both positive and negative, in a balanced way.

Many claims that insights into the firm's business model to addressees both regular financial and nonfinancial reporting would increase firm performance (Busco et al., 2013; Alwi et al.,2013). In order to investigate whether these claims are true, this study examines the association between sustainable reporting and firms performance.

\section{Literature Review}

\section{Studies on Sustainability Reporting}

Extent studies has examined factors determining the inclusion of sustainability reporting in corporate reports (Bear et al., 2010; Da Silva Monteiro \& Aibar-Guzmán, 2010; Gallo \& Christensen, 2011; Möller \& Verbeeten, 2011; Dah \& Jizi, 2016; Chang \& Mcllkenny, 2017; Anazonwu et al., 2018; Dissanayake et al., 2019; Kamarudin et al., 2012). The studies argue that factors such as the size of the company, corporate governance factors, and the intrinsic motivation of the management are among elements that influence the decision to implement the sustainable reporting. Other than the characteristics of a firm, other studies (Jiang \& Fu, 2019; Manes-Rossi et al., 2018; Latridis, 2013) also found the evidence that the strength of corporate governance such as optimum board size and the representation of outside directors have positive associations with sustainability disclosure.

A strand of research examined the complexity and challenges behind the reasons of providing such reports. that the expected benefit of sustainability practices may not be apparent. 
According to Kang et al (2010) there is a possibility that sustainability engagement may hinder optimal resource allocation, which could deter firms from their ultimate objective of maximizing the wealth of shareholders. This is due to the fact that in preparation of sustainability reports, firms need to face tensions in balancing the often divergent economic, social, and environmental goals. To a certain extent, firms may be lured towards 'greenwashing', as seen in the case of Volkswagen emission scandals, where incomplete or false information was intentionally provided to legitimately appear sustainability-oriented in order to gain economic benefits (Kamarudin et al., 2021). In addition, a study by Chen et al (2015) showed that some firms tended to apply for repetitive disclosures in order to suppress other disclosures, providing evidence for the manipulative power of management regarding these reports.

Previous studies on sustainability reporting have examined the benefit of sustainability practices and value creation. The studies found that commitment towards sustainable reports allows firms to gain competitive advantage (Hart \& Milstein, 2003; Porter \& Kramer, 2011) from the efficient allocation of firm-specific resources and capabilities that are inimitable by competitors (Barney, 1991; Rumelt, 1987). It is also found that embedding corporate sustainability agenda stimulates innovation (Porter \& Van der Linde, 1995), motivates employees to exert greater effort (Fauver et al., 2018) and strengthens a firm's resilience to external shocks (Desjardine et al., 2019). Friede et al (2015); Platonova et al (2018) also suggest that commitment towards sustainability is value-enhancing and thus could positively impacts the financial performance of firms.

Hypothesis Development

Several studies have proposed that sustainability reporting disclosures would increase business effectiveness and create value (Zamfir et al., 2017; Ouvrard et al., 2020; Nosratabadi et al., 2020). The evidence of the relationship between corporate sustainability reporting and financial performance, however, is mixed. There was some evidence of support for sustainability reporting, for example, and costly corporate social responsibility initiatives would divert managers from maximizing shareholder wealth (Liang \& Renneboog, 2016). In contrast, many studies perceived that corporate sustainability is essential in mitigating risk, especially the negative consequences resulting from irresponsible acts of a firm to society and the environment (Latridis, 2013). Besides, sustainability reporting signals the business conduct to users (Sweeney \& Coughlan, 2008; McWilliams \& Siegel; 2000; Hu et al., 2020). Thus, for example, corporate social responsibility strategies could positively be associated with business performance.

Al Hawaj \& Buallay (2021) added a new perspective to the sustainability reporting on integrating macroeconomic data. For ten years, from 2008 to 2017, data was collected from 3,000 companies in 80 different countries (cumulatively 23,738 observations). The empirical data show that there are disparities in the influence of sustainability reporting (ESG) on a firm's operational performance (ROA), financial performance (ROE), and market performance (TQ) across the seven sectors. This study offers a baseline for organisations intending to adopt sustainability reporting by contributing to the literature of sustainability accounting by providing a systematic depiction of cross-sectorial ESG reporting.

On the positive side, many studies have found the benefits of sustainability reporting. In Italy, for example, a study on multinational companies and private and public organizations suggested that the sustainability risk disclosure positively influenced by sustainability experience and international presence but was not affected by the presence of external insurance (Truant et al., 2017). Thus, by disclosing environmental information, experts are 
continually looking for new ways to protect the reputation of and benefits to stakeholders, improve eco-performance (Yu et al., 2018; Orlitzky \& Swanson, 2012; Ismail et al., 2012), or explore various existing relationships between sustainability reporting and the disclosure of ethical-social-environmental risks (Truant et al., 2017, Buchan, 2012; Grieco, 2015; Cameron, 2010; Costa \& Pesci, 2016; Bice, 2015; Schneider \& Meins, 2012, Wan Ismail et al., 2005).

Sustainable reporting also leads to better performance as the concerns for environment and creation of values would improve corporate reputation and thus gain positive implications. However, there are conflicting conclusions in the literature in the context of corporate reputation and sustainability reporting (Landau et al., (2020); Lozano et al., 2016; Kang \& Liu, 2014; Heinze et al., 1999; Amin et al., 2013). On one hand, corporate responsibility commitments could positively impact productivity through proactive communication and motivating purchase intention (Heinze et al., 1999; Cupertino et al., 2019; Dang et al., 2018). Besides, sustainable reporting could tarnish corporate reputation if negative involvements are revealed. A study by Ceulemans et al (2015) also found that the benefit of sustainable reporting is mixed. From a sample of 64 educational institutions around the world, the study found that 23 demonstrated positive aspects based on the internal motivations expressed through the awareness of sustainability and improvement of the communication with their stakeholders. Nonetheless, there are also the negative impacts which is due to the lack of inclusion of the material effects in the reports, the lack of external involvement of the stakeholders, the lack of implementation of sustainability reporting in the operation (Ceulemans et al., 2015).

Based on the argument that sustainable reporting leads to value creation, and enhanced firms performance, the following hypothesis is tested:

Hypothesis $1\left(\mathrm{H}_{1}\right)$ : Sustainability reporting is positively associated with financial performance.

\section{Research Methodology}

This study is a quantitative in nature to examine the relationship between variables. The research design used in this study is correlational research that uses a Weighted Least Squares regression on equation using the inverse number of observations in each country as a weight. (Salkind, 2014).

\section{Sample Selection}

The data cover the period 2011-2018 obtained from various sources. We extracted the financial data from Thomson Reuters Fundamentals, while the country-level data were extracted from annual World Economic Forum reports and the World Bank database. We deleted all missing observations. Our final sample consists of 24,029 firm-year observations from 14 countries: China, Egypt, Greece, Hungary, India, Malaysia, Pakistan, the Philippines, Poland, Russia, South Africa, Thailand, Turkey and United Arab Emirates. We winsorised the observations that fell in the top and bottom one per cent of all continuous variables to mitigate the influence of outliers.

\section{Regression Model}

As our number of observations varied substantially across countries, we employ a Weighted Least Squares regression on equation (1) using the inverse number of observations in each country as a weight. We followed the approach in prior studies (Jaggi \& Low, 2011; Lang \& Sul, 2014) to ensure that the results are not biased by more heavily represented countries. 


$$
\begin{aligned}
R O A=\alpha_{0}+\beta_{1} S U S T+ & \beta_{2} S I Z E+\beta_{3} L E V+\beta_{4} L I T+\beta_{5} M T B+\beta_{6} C O M P T+\beta_{7} A G E+ \\
& \beta_{8} L G D P+\vartheta_{1-n} \text { Fixed_effects } t+\varepsilon_{i t}
\end{aligned}
$$

Where ROA is the return on assets; SUST is a dummy variable that takes value 1 if the company discloses sustainable reporting, otherwise 0; SIZE is the natural logarithm of total assets; LEV is the ratio of total liabilities over the total assets; LIT is a dummy variable of high-litigation industries, classified as 1 if the SIC codes were between 2833-2836, 3570-3577, 3600-3674, 5200-5961 and 7370-7370, otherwise 0 (Ashbaugh \& LaFond, 2003); MTB is the ratio of market-to-book value; COMP is the proxy for industry competition measured as the sum of the squares of the market shares (calculated based on total assets) of all the firms in five industries classification of Fama and French (1997) has multiplied with negative one; SARS is the index of strength of the accounting and reporting standards issued by the World Economic Forum is higher than the mean value; LGDP is the natural logarithm of gross domestic product per capita in U.S. dollars from the World Bank; and Fixed_effects are controls for industry and year effects.

\section{Discussion of Results}

\section{Descriptive Statistics}

Table 1 presents descriptive statistics for firm-level variables and country-level variables. The result shows that the average ROA is 0.046 , with values ranging from -0.498 and 0.374 . The mean value for SUST is 0.052 , indicating that 5.2 per cent of the sample reports sustainable reporting. For the control variables, the mean for SIZE is 18.908 with a range between 13.313 and 24.455. The variable LEV. has a mean value of 0.231 with a value ranging from 0.000 and 1.146. A dummy for LIT has a mean value of 0.144 , indicating that 14.4 per cent of the sample are from high litigious industries. Other variables, MTB, COMP, and AGE, have mean values of $2.218,-0.087$, and 23.317 , respectively. The mean value for LIT is 0.181 , indicating that $18.1 \%$ of the sample are from highly litigious industry.

Table 1: Descriptive Statistics

\begin{tabular}{|l|l|l|l|l|}
\hline Variable & Mean & $\begin{array}{l}\text { Std. } \\
\text { Dev. }\end{array}$ & Min & Max \\
\hline ROA & 0.046 & 0.103 & -0.498 & 0.374 \\
\hline SUST & 0.052 & 0.222 & 0.000 & 1.000 \\
\hline SIZE & 18.908 & 2.077 & 13.313 & 24.455 \\
\hline LEV & 0.231 & 0.217 & 0.000 & 1.146 \\
\hline LIT & 0.144 & 0.351 & 0.000 & 1.000 \\
\hline MTB & 2.218 & 3.829 & -2.323 & 32.950 \\
\hline COMP & -0.087 & 0.092 & -0.979 & -0.013 \\
\hline AGE & 23.317 & 14.134 & 4.000 & 57.000 \\
\hline SARS & 4.855 & 0.474 & 3.766 & 6.577 \\
\hline LGDP & 7.232 & 1.293 & 5.164 & 9.015 \\
\hline
\end{tabular}

Table 2 presents simple correlations among the variables. The result shows that ROA is positively correlated with several variables, which are SUST, SIZE, LIT, MTB, COMP, AGE and LGDP. This is reasonable as the variables are expected to contribute towards firms 
performance. We also observed that LEV has negative relationship with ROA, consistent with the expectation that highly leveraged firms would have higher cost of capital, which could possibly decrease firms' profitability. More importantly, the correlation matrix also shows that the correlations between the independent variables are relatively low, hence suggesting that multicollinearity is unlikely to be an issue in the multivariate regression analyses.

Table 2: Correlation Matrix

\begin{tabular}{|l|l|l|l|l|l|}
\hline & ROA & SUST & SIZE & LEV & LIT \\
\hline ROA & $1.000^{* * *}$ & & & & \\
\hline SUST & $0.088^{* * *}$ & 1.000 & & & \\
\hline SIZE & $0.133^{* * *}$ & $0.418^{* * *}$ & 1.000 & & \\
\hline LEV & $-0.298^{* * *}$ & 0.002 & $0.133^{* * *}$ & 1.000 & \\
\hline LIT & $0.031^{* * *}$ & $-0.028^{* * *}$ & $-0.049^{* * *}$ & $-0.114^{* * *}$ & 1.000 \\
\hline MTB & $0.080^{* * *}$ & $0.039^{* * *}$ & $-0.045^{* * *}$ & $-0.087^{* * *}$ & $0.052^{* * *}$ \\
\hline COMP & $0.012^{* * *}$ & $-0.082^{* * *}$ & $0.025^{* * *}$ & $0.073^{* * *}$ & $-0.080^{* * *}$ \\
\hline AGE & $0.034^{* * *}$ & $0.091^{* * *}$ & -0.001 & $0.041^{* * *}$ & $-0.078^{* * *}$ \\
\hline SARS & 0.011 & $0.183^{* * *}$ & $-0.135^{* * *}$ & $-0.045^{* * *}$ & -0.001 \\
\hline LGDP & $0.021^{* * *}$ & $-0.094^{* * *}$ & $0.251^{* * *}$ & $0.044^{* * *}$ & $0.124^{* * *}$ \\
\hline & & & & & \\
\hline & MTB & COMP & AGE & SARS & LGDP \\
\hline MTB & 1.000 & & & & \\
\hline COMP & $0.027^{* * *}$ & 1.000 & & & \\
\hline AGE & $-0.042^{* * *}$ & $0.040^{* * *}$ & 1.000 & & \\
\hline SARS & $-0.045^{* * *}$ & $-0.024^{* * *}$ & $0.144^{* * *}$ & 1.000 & \\
\hline LGDP & $0.149^{* * *}$ & $0.368^{* * *}$ & $-0.256^{* * *}$ & $-0.405^{* * *}$ & 1.000 \\
\hline Asterisk den & 0 Statistical & SIgnicance & & \\
\hline
\end{tabular}

Asterisks denote statistical significance at the $1 \%\left({ }^{* * *}\right), 5 \%\left({ }^{* *}\right)$, or $10 \%\left({ }^{*}\right)$ levels, respectively.

Main Results

Table 3 presents the regression estimates for the effect of sustainability reporting on firm performance.

Table 3: Regression Estimates

\begin{tabular}{|l|l|l|l|}
\hline Variable & \multicolumn{1}{|c|}{ Coef. } & t-value & p-value \\
\hline SUST & $0.008^{* *}$ & 2.49 & 0.013 \\
\hline SIZE & $0.018^{* * *}$ & 30.77 & 0.000 \\
\hline LEV & $-0.170^{* * *}$ & -56.22 & 0.000 \\
\hline LIT & $-0.006^{* *}$ & -2.23 & 0.026 \\
\hline MTB & $0.002^{* * *}$ & 10.23 & 0.000 \\
\hline COMP & $0.048^{* * *}$ & 6.25 & 0.000 \\
\hline AGE & $0.001^{* * *}$ & 6.20 & 0.000 \\
\hline SARS & 0.001 & 0.69 & 0.493 \\
\hline LGDP & $-0.005^{* * *}$ & -7.53 & 0.000 \\
\hline Fixed Effects & Included & & \\
\hline Obs & 24,029 & & \\
\hline Adj R-squared & 0.1689 & & \\
\hline F-stat & 59.85 & & \\
\hline
\end{tabular}

Asterisks denote statistical significance at the $1 \%\left({ }^{* * *}\right), 5 \%\left({ }^{* *}\right)$, or $10 \%\left(^{*}\right)$ levels, respectively. 
We find that the coefficient for SUST is positive and significant, showing that in sustainability reporting is associated with high firm performance. This finding supports the notion that firm with high financial performance have greater tendency to produce sustainability reporting compared to firms with poor financial performance.

The regression estimates also show that the coefficient of the control variables, which are SIZE, MTB, COMP, AGE, and LGDP are positively significant $(p<0.01)$, suggesting that ROA is associated with these variables, consistent with the evidence from prior studies. We also find the coefficient for $L E V, L I T$ and $L G D P$ are positively significant $(p<0.01)$, suggesting that lower financial performance in firms with high-risk firms, high litigious firms and in countries with high income per capita.

\section{Conclusion}

This research tests and finds that sustainability reporting results in high financial performance in emerging market. This finding is consistent with prior studies that sustainability reporting disclosure would increase firm's profit through greater value creation (Hu et al., 2020; Truant et al., 2017; Yu et al., 2018), greater competitive advantage (Hart \& Milstein, 2003; Porter \& Kramer, 2011), more efficient allocation of firm's resources (Barney, 1991; Rumelt, 1987), greater stimulation of innovation (Porter \& Van der Linde, 1995), better employees' motivation (Fauver et al., 2018) and stronger resilient to external shocks (Desjardine et al., 2019). Investors could benefit from sustainability reporting as it helps protect shareholders' investment by promoting high-quality information. Our study provides valuable insights to investors and policymakers, especially in emerging markets, in terms of promoting sustainability reporting and providing incentive to disclosing firms. Going forward, we encourage more research on sustainability reporting and incorporating other institutional variables such as investor protection and culture.

\section{Acknowledgments}

The authors thank the editor and anonymous reviewers of the International Journal of Academic Research in Business and Social Science for insightful and constructive comments. The research is financially supported by the UITM-UNAIR Matching Grant No 100-TNCPI/INT 16/6/2 (027/2020).

\section{References}

Al Hawaj, A. Y., \& Buallay, A. M. (2021). A worldwide sectorial analysis of sustainability reporting and its impact on firm performance. Journal of Sustainable Finance \& Investment, 1-25. https://doi.org/10.1080/20430795.2021.1903792

Alwi, M., Wan Ismail, W. A., \& Kamarudin, K. A. (2013). The effectiveness of audit committee in relation to financial reporting fraud. In Proceeding of The 5th International Conference on Financial Criminology (ICFC), 332-344.

Amin, J. M., Saringat, S. M., Hassan, H., and Ismail, W. A. W. (2013). Intellectual capital disclosure in Malaysian public listed companies, IEEE Business Engineering and Industrial Applications Colloquium, Art. No. 6560223, 703-708.

Anazonwu, H. O., Egbunike, F. C., \& Gunardi, A. (2018). Corporate board diversity and sustainability reporting: A study of selected listed manufacturing firms in Nigeria. Indonesian Journal of Sustainability Accounting and Management, 2(1), 65-78. https://doi.org/10.28992/ijsam.v2i1.52

Ashbaugh, H., \& LaFond, R. (2003). Reporting incentives and the quality of non-US firms 
working capital accruals. Working paper, University of Wisconsin.

Barney, J. (1991). Firm resources and sustained competitive advantage. Journal of management, 17(1), 99-120. https://doi.org/10.1177/014920639101700108

Bear, S., Rahman, N., \& Post, C. (2010). The impact of board diversity and gender composition on corporate social responsibility and firm reputation. Journal of business ethics, $97(2)$, 207-221. https://doi.org/10.1007/s10551-010-0505-2

Ben-Amar, W., Chang, M., \& Mcllkenny, P. (2017). Board gender diversity and corporate response to sustainability initiatives: Evidence from the carbon disclosure project. Journal of business ethics, 142(2), 369-383. https://doi.org/10.1007/s10551-015-27591

Bice, S. (2015). Bridging corporate social responsibility and social impact assessment. Impact Assessment and Project Appraisal, 33(2), 160-166. https://doi.org/10.1080/14615517.2014.983710

Buchan, D. (2012). New directions in social impact assessment: Conceptual and methodological advances. Impact Assessment and Project Appraisal. 30, 137-138.

Busco, C., Frigo, M. L., Riccaboni, A., \& Quattrone. P. (2013). Integrated reporting: Concepts and Cases that Redefine Corporate Accountability. In Springer International Publishing. https://doi.org/10.4324/9781351284646-18

Cameron, J., Gardner, C., \& Veenhuyzen, J. (2010). Social Accounting: A practical guide for small community organisations and enterprises. Centre for Urban and Regional Studies, The University of Newcastle, Australia. Accessed from http://www. communityeconomies.org/site/assets/media/Jenny_Cameron/Social_Accounting_Ma nual_Version_2_July_2010.pdf on, 1(08).

Ceulemans, K., Lozano, R., \& Alonso-Almeida, M. D. M. (2015). Sustainability reporting in higher education: Interconnecting the reporting process and organisational change management for sustainability. Sustainability, 7(7), 8881-8903.

https://doi.org/10.3390/su7078881

Chen, L., Feldmann, A., \& Tang, O. (2015). The relationship between disclosures of corporate social performance and financial performance: Evidences from GRI reports in manufacturing industry. International Journal of Production Economics, 170, 445-456. https://doi.org/10.1016/j.ijpe.2015.04.004

Costa, E., \& Pesci, C. (2016). Social impact measurement: why do stakeholders matter?. Sustainability Accounting, Management and Policy Journal. 7 (1), 99-124. https://doi.org/10.1108/SAMPJ-12-2014-0092

Cupertino, S., Consolandi, C., \& Vercelli, A. (2019). Corporate social performance, financialization, and real investment in US manufacturing firms. Sustainability, 11(7), 1836. https://doi.org/10.3390/su11071836

Dang, C., Li, Z. F., \& Yang, C. (2018). Measuring firm size in empirical corporate finance. Journal of banking \& finance, 86, 159-176. https://doi.org/10.1016/j.jbankfin.2017.09.006

DesJardine, M., Bansal, P., \& Yang, Y. (2019). Bouncing back: Building resilience through social and environmental practices in the context of the 2008 global financial crisis. Journal of Management, 45(4), 1434-1460. https://doi.org/10.1177/0149206317708854

Dissanayake, D., Tilt, C., \& Qian, W. (2019). Factors influencing sustainability reporting by Sri Lankan companies. Pacific Accounting Review. 31(1), 84-109.

https://doi.org/10.1108/PAR-10-2017-0085

Fama, E. F., \& French, K. R. (1997). Industry costs of equity. Journal of financial economics, 43(2), 153-193. https://doi.org/10.1016/S0304-405X(96)00896-3 
Fauver, L., McDonald, M. B., \& Taboada, A. G. (2018). Does it pay to treat employees well? International evidence on the value of employee-friendly culture. Journal of Corporate Finance, 50, 84-108. https://doi.org/10.1016/j.jcorpfin.2018.02.003

Friede, G., Busch, T., \& Bassen, A. (2015). ESG and financial performance: aggregated evidence from more than 2000 empirical studies. Journal of Sustainable Finance \& Investment, 5(4), 210-233. https://doi.org/10.1080/20430795.2015.1118917

Gallo, P. J., \& Christensen, L. J. (2011). Firm size matters: An empirical investigation of organizational size and ownership on sustainability-related behaviors. Business \& Society, 50(2), 315-349. https://doi.org/10.1177/0007650311398784

Gamerschlag, R., Möller, K., \& Verbeeten, F. (2011). Determinants of voluntary CSR disclosure: empirical evidence from Germany. Review of Managerial Science, 5(2-3), 233-262. https://doi.org/10.1007/s11846-010-0052-3

Grieco, C. (2015). Assessing social impact of social enterprises: Does one size really fit all? SpringerBriefs in Business. https://doi.org/10.1007/978-3-319-15314-8

Hart, S. L., \& Milstein, M. B. (2003). Creating sustainable value. Academy of Management Perspectives, 17(2), 56-67. https://doi.org/10.5465/ame.2003.10025194

Heinze, D., Sibary, S., \& Sikula, Sr, A. (1999). Relations among corporate social responsibility, financial soundness, and investment value in 22 manufacturing industry groups. Ethics \& Behavior, 9(4), 331-347. https://doi.org/10.1207/s15327019eb0904_4

latridis, G. E. (2013). Environmental disclosure quality: Evidence on environmental performance, corporate governance and value relevance. Emerging Markets Review, 14, 55-75. https://doi.org/10.1016/j.ememar.2012.11.003

Ismail, W. A. W., Ahmad, R. A., Kamarudin, K. A., Yahaya, R. (2005). Corporate Failure Prediction: An Investigation of PN4 Companies. Journal of Financial Reporting and Accounting, 3 (1), 1-16.

Jaggi, B., \& Low, P. Y. (2011). Joint effect of investor protection and securities regulations on audit fees. The International Journal of Accounting, 46(3), 241-270. https://doi.org/10.1016/j.intacc.2011.07.003

Jiang, C., \& Fu, Q. (2019). A Win-win outcome between corporate environmental performance and corporate value: From the perspective of stakeholders. Sustainability, 11(3), 921. https://doi.org/10.3390/su11030921

Kamarudin, K. A., Ariff, A. M., \& Ismail, W. A. W. (2021). Product market competition, board gender diversity and corporate sustainability performance: international evidence. Journal of Financial Reporting and Accounting. https://doi.org/10.1108/JFRA-01-20210020

Kamarudin, K. A., Ismail, W. A. W., and Samsuddin, M. E. (2012), The role of the audit committee in moderating the negative effect of Non-Audit services on earnings quality, 2nd International Conference on Management, Holiday Villa Beach Resort and Spa, Langkawi Kedah.

Kang, H. H., \& Liu, S. B. (2014). Corporate social responsibility and corporate performance: A quantile regression approach. Quality \& Quantity, 48(6), 3311-3325. https://doi.org/10.1007/s11135-013-9958-6

Kang, Y., Ryu, M. H., \& Kim, S. (2010). Exploring sustainability management for telecommunications services: A case study of two Korean companies. Journal of World Business, 45(4), 415-421. https://doi.org/10.1016/j.jwb.2009.08.003

Landau, A., Rochell, J., Klein, C., \& Zwergel, B. (2020). Integrated reporting of environmental, social, and governance and financial data: Does the market value integrated 
reports? Business Strategy and the Environment, 29(4), 1750-1763.

Lang, M., \& Sul, E. (2014). Linking industry concentration to proprietary costs and disclosure: Challenges and opportunities. Journal of Accounting and Economics, 58(2-3), 265-274. https://doi.org/10.1016/j.jacceco.2014.08.008

Latridis, G. E. (2013). Environmental disclosure quality: Evidence on environmental performance, corporate governance and value relevance. Emerging Markets Review, 14, 55-75. https://doi.org/10.1016/j.ememar.2012.11.003

Liang, H., \& Renneboog, L. (2016). Corporate donations and shareholder value. European Corporate Governance Institute (ECGI) (No. 491, p. 1). Finance Working Paper. https://dx.doi.org/10.2139/ssrn.2932092

Lozano, R., Nummert, B., \& Ceulemans, K. (2016). Elucidating the relationship between sustainability reporting and organisational change management for sustainability. Journal of Cleaner Production, 125, 168-188.

https://doi.org/10.1016/j.jclepro.2016.03.021

Manes-Rossi, F., Tiron-Tudor, A., Nicolò, G., \& Zanellato, G. (2018). Ensuring more sustainable reporting in Europe using non-financial disclosure-De facto and de jure evidence. Sustainability, 10(4), 1162. https://doi.org/10.3390/su10041162

McWilliams, A., \& Siegel, D. (2000). Corporate social responsibility and financial performance: correlation or misspecification?. Strategic management journal, 21(5), 603-609. https://doi.org/10.1002/(SICI)1097-0266(200005)21:5<603::AID-SMJ101>3.0.CO;2-3

Melloni, G., Caglio, A., and Perego, P. (2017), "Saying more with less? Disclosure conciseness, completeness and balance in integrated reports", Journal of Accounting and Public Policy, 36 (3), pp. 220-238.

Nosratabadi, S., Pinter, G., Mosavi, A., \& Semperger, S. (2020). Sustainable banking; evaluation of the European business models. Sustainability, 12(6), 2314. https://doi.org/10.3390/su12062314

Orlitzky, M., \& Swanson, D. L. (2012). Assessing stakeholder satisfaction: Toward a supplemental measure of corporate social performance as reputation. Corporate Reputation Review, 15(2), 119-137. https://doi.org/10.1057/crr.2012.3

Ouvrard, S., Jasimuddin, S. M., \& Spiga, A. (2020). Does sustainability push to reshape business models? Evidence from the European wine industry. Sustainability, 12(6), 2561. https://doi.org/10.3390/su12062561

Platonova, E., Asutay, M., Dixon, R., \& Mohammad, S. (2018). The impact of corporate social responsibility disclosure on financial performance: Evidence from the GCC Islamic banking sector. Journal of Business Ethics, 151(2), 451-471. https://doi.org/10.1007/s10551-016-3229-0

Porter, M. E., \& Kramer, M. R. (2011). Creating shared value. Harvard Business Review, 89(1/2) 1-17.

Porter, M. E., \& Der Linde, V. C. (1995). Toward a new conception of the environmentcompetitiveness relationship. Journal of economic perspectives, 9(4), 97-118. https://doi.org/10.1257/jep.9.4.97

Rumelt, R. P. (1987). Theory, strategy, and entrepreneurship. In Handbook of entrepreneurship research. 137(158). 1-22. In Springer, Boston, MA.

Salkind, N. J. (2014). 100 questions (and answers) about statistics. SAGE Publications.

Schneider, A., \& Meins, E. (2012). Two dimensions of corporate sustainability assessment: Towards a comprehensive framework. Business Strategy and the Environment, 21(4), 211-222. https://doi.org/10.1002/bse.726 
Spitzeck, H., and Chapman, S. (2012), "Creating shared value as a differentiation strategy the example of BASF in Brazil", Corporate Governance, 12(4), 499-513. https://doi.org/10.1108/14720701211267838

Sweeney, L., \& Coughlan, J. (2008). Do different industries report corporate social responsibility differently? An investigation through the lens of stakeholder theory. Journal of Marketing Communications, 14(2), 113-124. https://doi.org/10.1080/13527260701856657

Truant, E., Corazza, L., \& Scagnelli, S. D. (2017). Sustainability and risk disclosure: An exploratory study on sustainability reports. Sustainability, 9(4), 636. https://doi.org/10.3390/su9040636

Ismail, W. A., Kamarudin, K. A., \& Ibrahim, M. K. (2005). Income smoothing and market perception of accounting numbers: An empirical investigation of extraordinary items. National Accounting Research Journal, 3(1), 49-70.

Ismail, W. A., Kamarudin, K. A., \& Othman, R. (2012). Assessment of Earnings Conservatism in Government-Linked Companies. Procedia - Social and Behavioral Sciences, 65, 650-655.

Yu, Y., Huang, J., \& Luo, N. (2018). Can more environmental information disclosure lead to higher eco-efficiency? Evidence from China. Sustainability, 10(2), 528. https://doi.org/10.3390/su10020528

Zamfir, A. M., Mocanu, C., \& Grigorescu, A. (2017). Circular economy and decision models among European SMEs. Sustainability, 9(9), 1507. https://doi.org/10.3390/su9091507 